2014s-23

\title{
Endogenous Changes in Tastes
}

Daniel Léonard, Ngo Van Long

\begin{tabular}{c}
\hline Série Scientifique \\
Scientific Series
\end{tabular}

Montréal

Février/February 2014

(C) 2014 Daniel Léonard, Ngo Van Long. Tous droits réservés. All rights reserved. Reproduction partielle permise avec citation du document source, incluant la notice (C).

Short sections may be quoted without explicit permission, if full credit, including (C) notice, is given to the source.
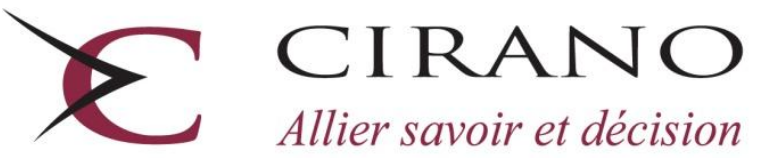

Allier savoir et décision

Centre interuniversitaire de recherche en analyse des organisations 


\section{CIRANO}

Le CIRANO est un organisme sans but lucratif constitué en vertu de la Loi des compagnies du Québec. Le financement de son infrastructure et de ses activités de recherche provient des cotisations de ses organisations-membres, d'une subvention d'infrastructure du Ministère de l'Enseignement supérieur, de la Recherche, de la Science et de la Technologie, de même que des subventions et mandats obtenus par ses équipes de recherche.

CIRANO is a private non-profit organization incorporated under the Québec Companies Act. Its infrastructure and research activities are funded through fees paid by member organizations, an infrastructure grant from the Ministère de l'Enseignement supérieur, de la Recherche, de la Science et de la Technologie, and grants and research mandates obtained by its research teams.

\section{Les partenaires du CIRANO}

\section{Partenaire majeur}

Ministère de l'Enseignement supérieur, de la Recherche, de la Science et de la Technologie

\section{Partenaires corporatifs}

Autorité des marchés financiers

Banque de développement du Canada

Banque du Canada

Banque Laurentienne du Canada

Banque Nationale du Canada

Banque Scotia

Bell Canada

BMO Groupe financier

Caisse de dépôt et placement du Québec

Fédération des caisses Desjardins du Québec

Financière Sun Life, Québec

Gaz Métro

Hydro-Québec

Industrie Canada

Intact

Investissements PSP

Ministère des Finances et de l'Économie

Power Corporation du Canada

Rio Tinto Alcan

Transat A.T.

Ville de Montréal

\section{Partenaires universitaires}

École Polytechnique de Montréal

École de technologie supérieure (ÉTS)

HEC Montréal

Institut national de la recherche scientifique (INRS)

McGill University

Université Concordia

Université de Montréal

Université de Sherbrooke

Université du Québec

Université du Québec à Montréal

Université Laval

Le CIRANO collabore avec de nombreux centres et chaires de recherche universitaires dont on peut consulter la liste sur son site web.

Les cahiers de la série scientifique (CS) visent à rendre accessibles des résultats de recherche effectuée au CIRANO afin de susciter échanges et commentaires. Ces cahiers sont écrits dans le style des publications scientifiques. Les idées et les opinions émises sont sous l'unique responsabilité des auteurs et ne représentent pas nécessairement les positions du CIRANO ou de ses partenaires.

This paper presents research carried out at CIRANO and aims at encouraging discussion and comment. The observations and viewpoints expressed are the sole responsibility of the authors. They do not necessarily represent positions of CIRANO or its partners. 


\title{
Endogenous Changes in Tastes
}

\author{
Daniel Léonard ${ }^{*}$, Ngo Van Long ${ }^{\dagger}$
}

\begin{abstract}
Résumé/abstract
Les parents se soucient de leurs enfants, dépensent des ressources pour les éduquer, ils leur lèguent un capital physique et/ou humain. Ici, nous montrons que les actions des parents ont une influence, non seulement sur les possibilités de production ouvertes aux enfants (par le biais du captital dont ils héritent), mais aussi sur leurs goûts et leurs attitudes. Nous étudions la dynamique résultant de cette idée. Plusieurs influences sont identifiées mais un résultat surprenant est que, si l'héritage a une grande influence sur l'attitude des gens envers le travail, l'évolution du stock de capital et du travail devient totalement imprévisible après quelques générations.
\end{abstract}

Mots clés : évolution de préférences, legs, chaos.

Parents care about their children, spend resources on educating them and bequeath them some physical and/or human capital. Here we argue that the actions of the parents have an influence, not only on the productive possibilities open to the children (through the capital they inherit) but also on their tastes and attitudes. We investigate the resulting dynamics of this idea. Several influences are identified but one startling result is that, if inheritance has a large influence on people's attitude to work, the pattern of behavior becomes completely unpredictable after a few generations.

Key words: Endogenous preferences, bequests, chaos.

Codes JEL : D11

\footnotetext{
${ }^{*}$ School of Economics, Flinders University. (Daniel.leonard@ flinders.edu.au)

${ }^{\dagger}$ CIRANO and Department of Economics, McGill University. (Ngo.Long@ mcgill.ca)
} 


\section{Introduction}

Parents care about their children, spend resources on educating them and bequeath them some physical and/or human capital. Here we argue that the actions of the parents have an influence, not only on the productive possibilities open to the children (through the captital they inherit) but also on their tastes and attitudes. This has been an accepted notion throughout history, although it was sometimes referred to as "good family background" or the reverse. We formalise this idea here and we investigate the resulting dynamics. ${ }^{1}$

\section{The Model}

For simplicity we treat the parents as a single unit or individual, and the children also. In period $t$ an individual has inherited capital $b_{t}$. They choose their consumption $c_{t}$, their labor $l_{t}$, and the bequests to their children $b_{t+1}$ so as to maximize their own utility which takes the form of a modified StoneGeary utility function where, for clarity, all parameters are positive

$$
V_{t}=\ln \left(c_{t}-x-\delta b_{t}\right)-\gamma\left(b_{t}\right)^{\epsilon} l_{t}+\beta \ln \left(b_{t+1}-\theta b_{t}\right)
$$

We restrict $\theta$ to be less than 1 . If $\theta$ were greater than or equal to 1 , the system would collapse unless the path of bequeathed wealth were forever increasing, precluding the possibility of fluctuations. The restriction $\theta<1$ does not preclude the monotonicity of the time path of wealth, nor does it preclude fluctuations. The dynamic behavior of wealth depends on the relationship between $\theta$ and other parameters, as we shall see.

\footnotetext{
${ }^{1}$ The notion that parents can intentionally or unintentionally influence the preferences of their children has received some attention in the economic literature; see e.g. Becker (1993), Bisin and Verdier (2001), Bala and Long (2005).
} 
We model the effect of inherited wealth on tastes by assuming that what individuals consider the minimum acceptable level of consumption consists of a fixed consumption level $x$ and a proportion $\delta$ of their own inherited wealth. This captures the idea that people born to riches are more demanding than people born poor. Wealth also affects their attitude to work: the wealthier they are the less they are inclined to work, or rather, they find it more painful or difficult. The last term in the utility function simply reflects the fact that they care for their children's well-being in the next period and wish to endow them; in so doing, they are also influenced by the inheritance they received from their parents. They are motivated by trying to improve their offsprings' situation relative to their own. Therefore the feelings of parents towards their children's wellbeing is a double-edged sword. Their caring entices them to endow their children well, but at the same time nourishes high expectations that may work to their detriment. There is, however, a very positive aspect to inherited high levels of capital. The children can earn more.

Income is earned from working and their capacity to earn is determined by their inherited wealth, $b_{t}$. However the new generation earns its living, it is undeniable that they obtain it from either skills or productive investments, usually a combination of both. Therefore the following formulation is appropriate

$$
y_{t}=A\left(b_{t}\right)^{\alpha} l_{t}
$$

where $0<\alpha \leq 1$. One could argue as did Rebello (1990) to introduce his $A K$ model, that $b_{t}$ is a combination of human and physical capital and that $\alpha$ is equal to 1 under constant returns to scale.

Their budget constraint is

$$
y_{t}=c_{t}+b_{t+1}
$$

The first order conditions are 


$$
\begin{gathered}
\frac{1}{c_{t}-x-\delta b_{t}}=\lambda_{t} \\
\frac{\beta}{b_{t+1}-\theta b_{t}}=\lambda_{t} \\
\gamma\left(b_{t}\right)^{\epsilon}=\lambda_{t} A\left(b_{t}\right)^{\alpha} \text { or } \lambda_{t}=\frac{\gamma}{A}\left(b_{t}\right)^{\epsilon-\alpha}
\end{gathered}
$$

From (5) and (6)

$$
\begin{gathered}
c_{t}-x-\delta b_{t}=A\left(b_{t}\right)^{\alpha} / \gamma\left(b_{t}\right)^{\epsilon} \\
b_{t+1}=\theta b_{t}+\frac{\beta A}{\gamma}\left(b_{t}\right)^{\alpha-\epsilon}
\end{gathered}
$$

Note that it is necessary that $b_{t}-\theta b_{t-1}>0$, for all $t$, for the utility function to be defined. This is always true in our formulation.

From (8) and (7) we have

$$
c_{t}=x+(\delta-\theta / \beta) b_{t}+b_{t+1} / \beta=x+\delta b_{t}+\frac{A}{\gamma}\left(b_{t}\right)^{\alpha-\epsilon}
$$

and with (3) we have

$$
y_{t}=x+(\delta+\theta) b_{t}+\left(\frac{1+\beta}{\beta}\right)\left(b_{t}\right)^{\alpha-\epsilon}
$$

and

$$
\begin{gathered}
l_{t}=\frac{y_{t}}{A\left(b_{t}\right)^{\alpha}} \\
l_{t}=\frac{x\left(b_{t}\right)^{-\alpha}}{A}+\frac{(\delta+\theta)\left(b_{t}\right)^{1-\alpha}}{A}+\left(\frac{1+\beta}{A \gamma}\right)\left(b_{t}\right)^{-\epsilon}
\end{gathered}
$$

REMARKS: The dynamics of the model are given by the non-linear firstorder difference equation (8). For parameter values such that $0<\epsilon<\alpha \leq 1$, the path of $b_{t}$ is monotone and the model quickly converges to a steady 
state. It is not our purpose here to investigate cases where children are not much influenced by their education or inheritance, quite the opposite. For parameter values such that $\epsilon>\alpha$, the path of $b_{t}$ may not be monotone. The paths of the other variables follow according to equations (9)-(11). Neither consumption nor income depend monotonically on inheritance (as long as $\epsilon>\alpha$ ) and labour does not always decrease with inheritance, unless $\alpha=$ 1. However, for most parameter values, consumption and income are very strongly positively correlated with inheritance while work is very strongly negatively correlated.

\section{Dynamics}

The main relation is (8) and the one-period steady state is ${ }^{2}$

$$
\bar{b}=\left(\frac{\beta A}{\gamma(1-\theta)}\right)^{\frac{1}{1-\alpha+\epsilon}} \text { or }(\bar{b})^{1-\alpha+\epsilon}=\frac{\beta A}{\gamma(1-\theta)}
$$

The behaviour of the state variable around the steady state can be precisely analyzed by taking the derivative of (8), and evaluate it at the steady state. $^{3}$ We obtain

$$
\frac{d b_{t+1}}{d b_{t}}=\theta+\frac{\beta A}{\gamma}(\alpha-\epsilon)\left(b_{t}\right)^{\alpha-\epsilon-1}
$$

When the slope equals -1 , the system becomes unstable. Using (12), we have the value for $\epsilon$ that does this

$$
\begin{aligned}
-1 & =\theta+\frac{\beta A}{\gamma}(\alpha-\epsilon) \frac{\gamma(1-\theta)}{\beta A}=\theta+(\alpha-\epsilon)(1-\theta), \\
1+\theta & =(\epsilon-\alpha)(1-\theta) \\
\epsilon & =\alpha+\frac{1+\theta}{1-\theta}
\end{aligned}
$$

\footnotetext{
${ }^{2}$ There is another steady state at $b=0$, which we disregard.

${ }^{3}$ Chang et al. (1983) analysed the stability property of a simple overlapping generations model. They did not consider chaotic behavior.
} 
The system is asymptotically stable when $\epsilon \in\left(\alpha, \alpha+\frac{1+\theta}{1-\theta}\right)$. The bifurcation occurs at the upper bound. Note that the value of $\epsilon$ at which the bifurcation occurs is an increasing function of $\theta$.Therefore the more parents care about their children's wealth (high $\theta$ ), the more unlikely it is that chaotic behaviour would occur, because the range of value of $\epsilon$ that is consistent with stability is larger.

The two-period steady state $\bar{B}$ is described by

$$
1-\theta^{2}=\boldsymbol{z}\left[\theta+(\theta+\boldsymbol{z})^{\alpha-\epsilon}\right], \text { where } \boldsymbol{z}=\frac{\beta A}{\gamma}(\bar{B})^{\alpha-\epsilon-1}
$$

This equation has no analytical solution for arbitrary parameter values and we need to resort to simulations to analyse the model. ${ }^{4}$

We choose $A=10, \alpha=1, \beta=\gamma=\theta=0.5, \delta=0.1$ and let $\epsilon$ take a range of values. Equation (14) has a single solution for small $\epsilon$ values and the paths of all variables are monotone after a few periods. Things change when $\epsilon$ reaches the bifurcation value, 4 in this example. There are now three steady states in (14). The solutions to that equation are illustrated in Figures 1-3 for $\epsilon$ values of 2, 4 and 6 . The most interesting case in when $\epsilon=6$ (or larger). Figures 4-7 show $b_{t+1}$ through to $b_{t+4}$, respectively, against $b_{t}$. There clearly is period-doubling. In Figures 8 and 9 , we depict $b_{t+10}$ and $b_{t+20}$. The $b$-values are bounded and fill the space. These figures have been drawn using 1000 periods. This clearly points to chaotic behaviour of the system. Furthermore, these simulations have been done using the initial condition $b_{0}=1.01 \bar{b}$, therefore very close to the one-period steady state. When altering the initial condition very slightly to $b_{0}=1.011 \bar{b}$, there is a definite change of pattern after a few periods. This is illustrated in Figure 10, which is to be compared with Figure 8. Numerically, this slight change in the initial condition makes $b_{t+10}$ change from 2.39 to 1.797 and $b_{t+20}$ change

\footnotetext{
${ }^{4}$ For analysis of chaotic behavior in non-linear dynamical systems in discrete time, see Devalney (1983) and Whitley (1983).
} 
from 1.5165 to 3.2956 , in the opposite direction. This sensitivity to initial conditions is another indication of chaotic behaviour. ${ }^{5}$

We have experimented with other parameter values. Surprisingly the value of $\alpha$ (from 0.05 to 1 ) makes little difference to the results. The value of $\theta$ does in the sense that higher values of $\theta$ require higher values of $\epsilon$ for the chaotic behaviour to develop, as we indicated before the simulation; the pattern remains the same, though. Figure 11 shows the evolution of $l_{t}$ against $b_{t}$. Larger bequests induce children to work less hard but this effect bottoms out after a while and the "mega wealthy" work about the same as the "very wealthy". Poorly endowed children work much harder. Consumption and inheritance move together as shown in Figure 12. In Figure 13 we have depicted the same pattern, with the slight change in initial condition indicated earlier. It confirms that the behaviour of the system is impossible to predict in practice.

\section{Conclusion}

In conclusion, we have demonstrated that the changes in tastes due to the size of the inheritance profoundly affect the behaviour of future generations. The more poorly endowed work harder but the pattern soon becomes very irregular if the effect of the size of the inheritance on the attitude to work is large. To paraphrase a well known saying, "Even if we understand history, it is not condemned to repeat itself."

\footnotetext{
${ }^{5}$ Indeed, when doing simulations on Excel, which has substantial, but finite capacities of calculation, if we start at $\bar{b}$, the system does not stay there and goes into chaotic mode after 40 periods or so. This is because $\bar{b}=(20)^{\frac{1}{6}}$, which Excel cannot calculate with perfect accuracy.
} 


\section{References}

[1] Bala, V. and N. V. Long (2005), International Trade and Cultural Diversity with Preference Selection, European Journal of Political Economy, Vol. 21, 143-162.

[2] Becker, G. (1993): Nobel Lecture: The Economic Way of Looking at Behavior, Journal of Political Economy, Vol. 101, 385-409.

[3] Bisin, A, and Verdier, T. (2001), The Economics of Cultural Transmissions and the Dynamics of Preferences, Journal of Economic Theory, Vol. 97, 298-319.

[4] Chang, W., M.C. Kemp, N.V. Long (1983), Dynamic Properties of a Simple Overlapping-Generations Model, Oxford Economic Papers, Vol. $35,366-372$

[5] Devaney, R. (1983), An Introduction to Chaotic Dynamical Systems. Addison-Wseley, New York.

[6] Rebelo, S. (1990), Long Run Analysis of Long Run Growth, Journal of Political Economy, Vol. 99(3), 500-521.

[7] Whitley, D. (1983), Discrete Dynamical Systems in Dimensions One and Two, Bull. London Math. Soc., Vol.15, 177-217. 


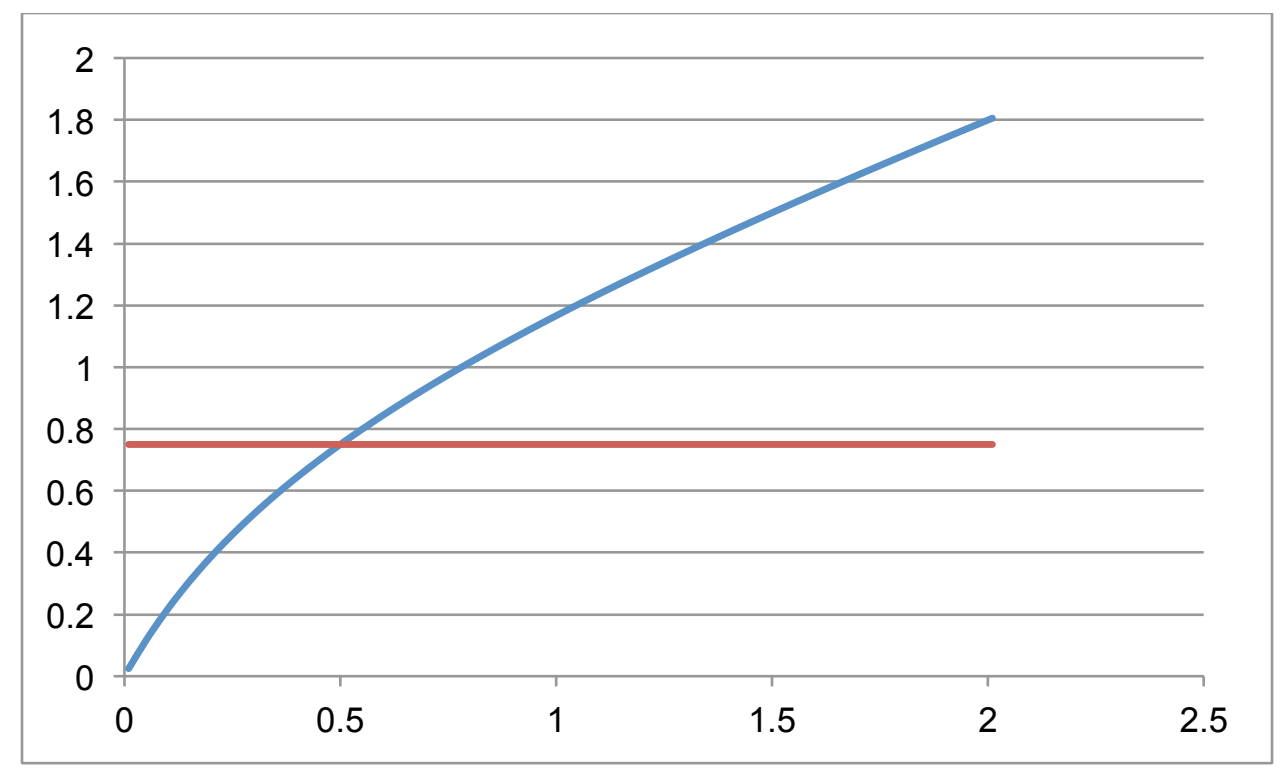

SS2 with epsilon $=2$

Figure1

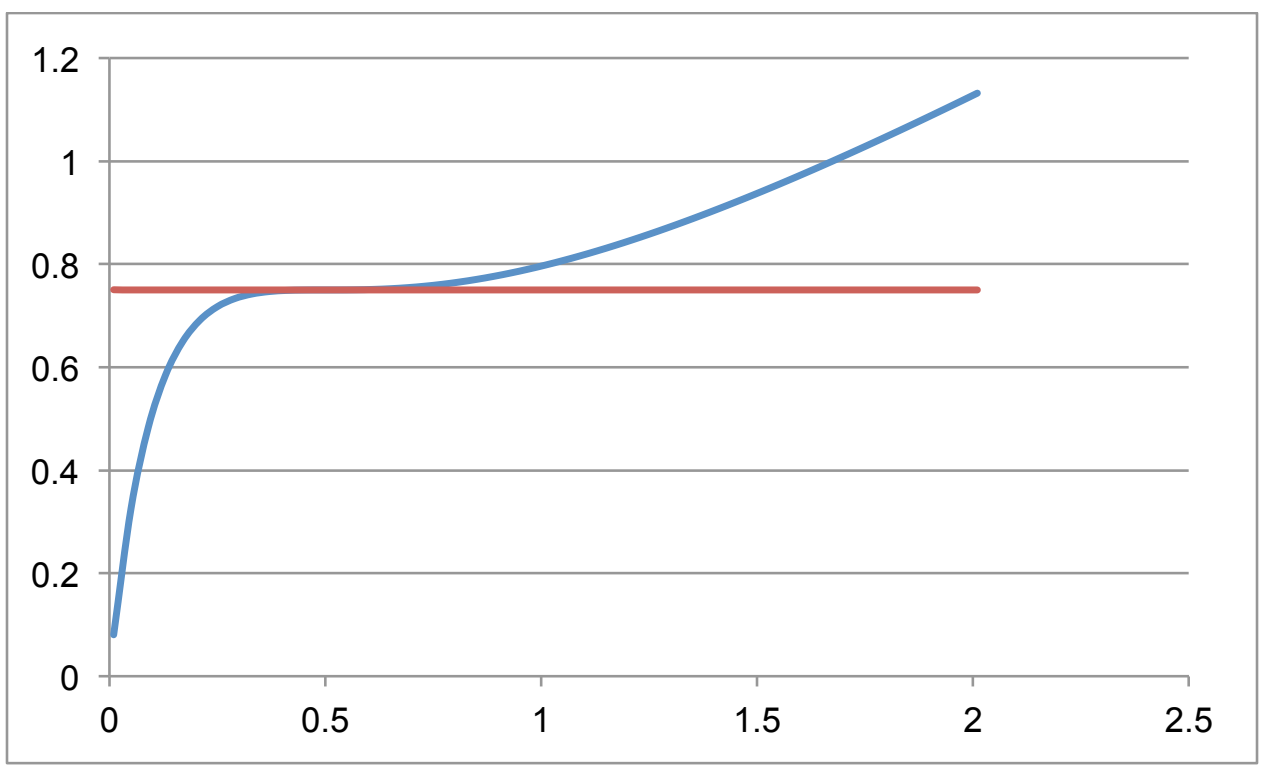

SS2 with epsilon $=4$

Figure2 


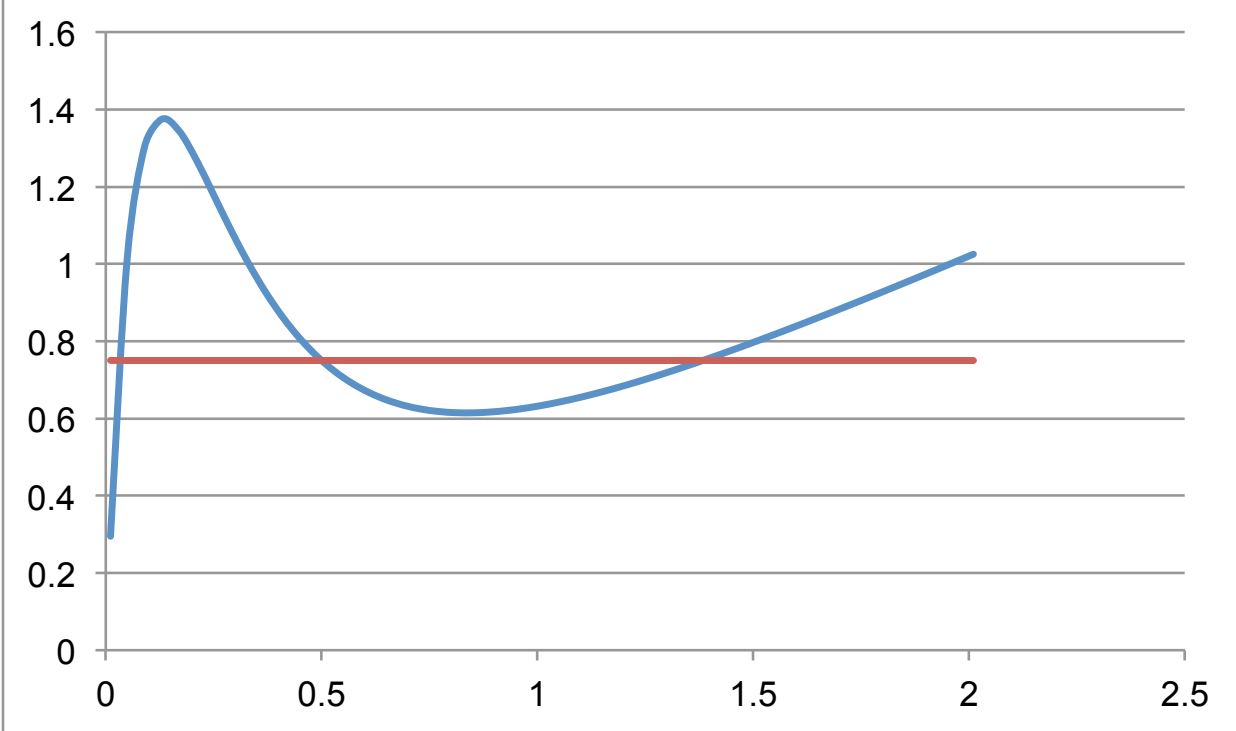

SS2 with epsilon $=6$

Figure3

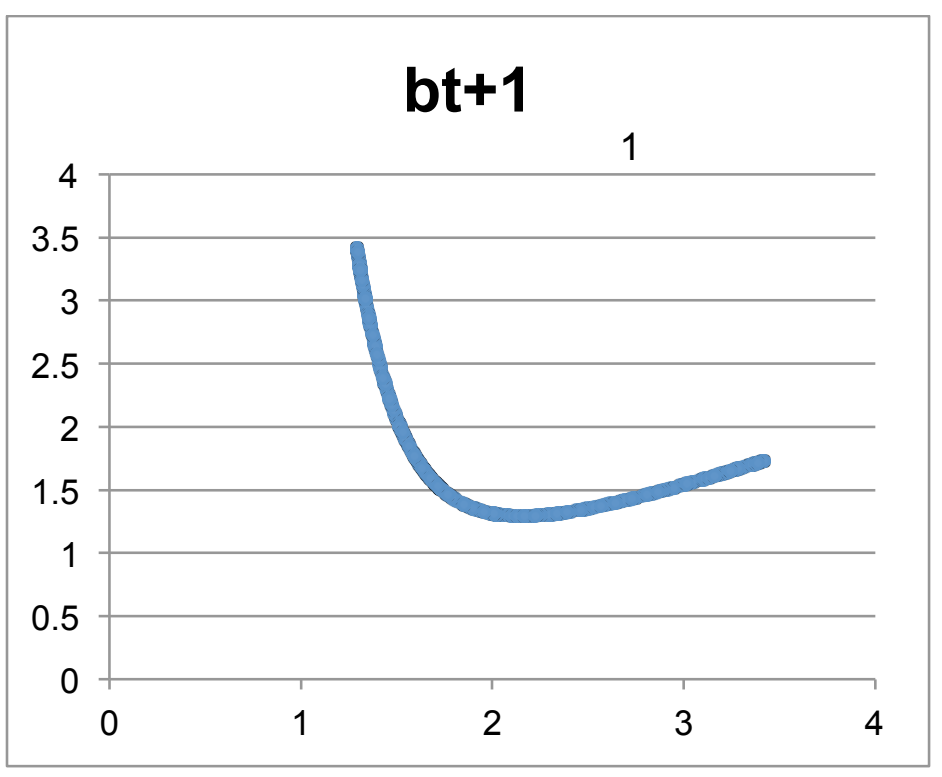

Figure 4 


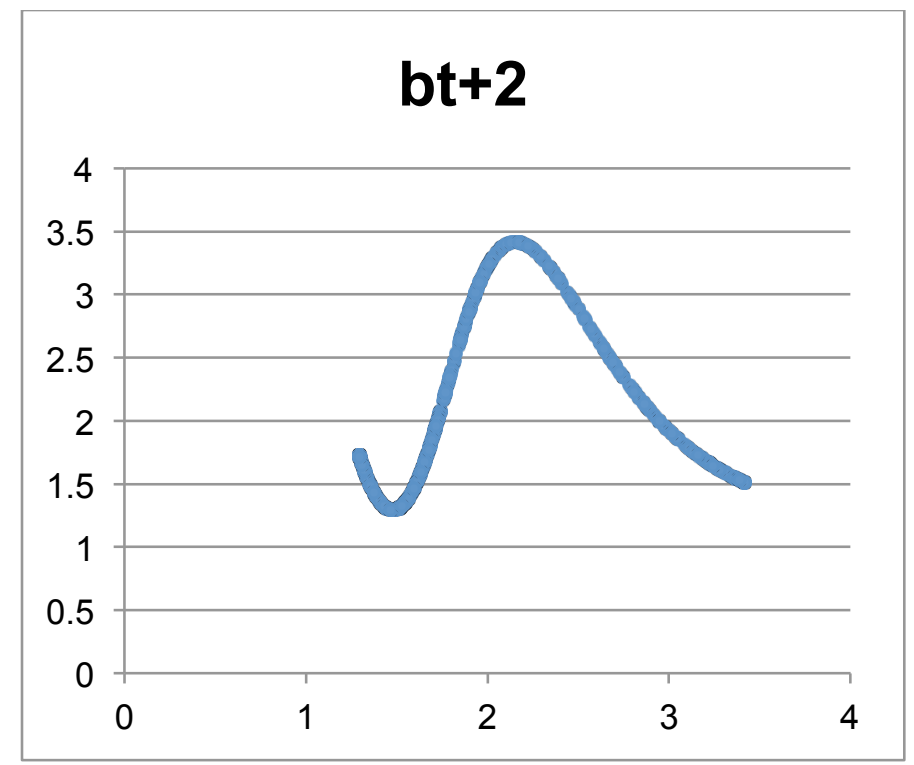

Figure 5

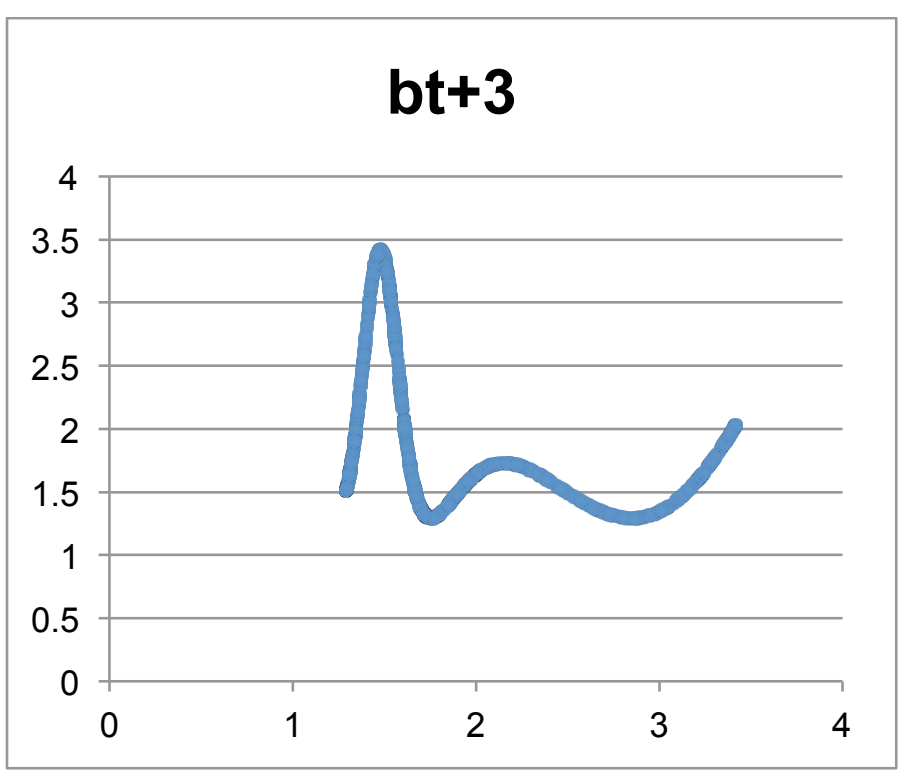

Figure 6 


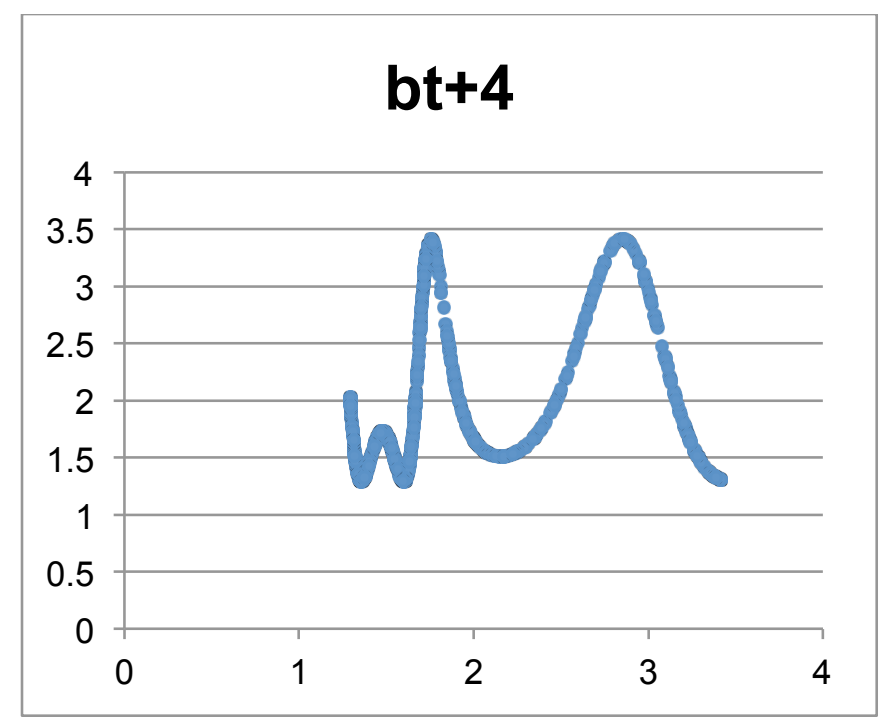

Figure 7

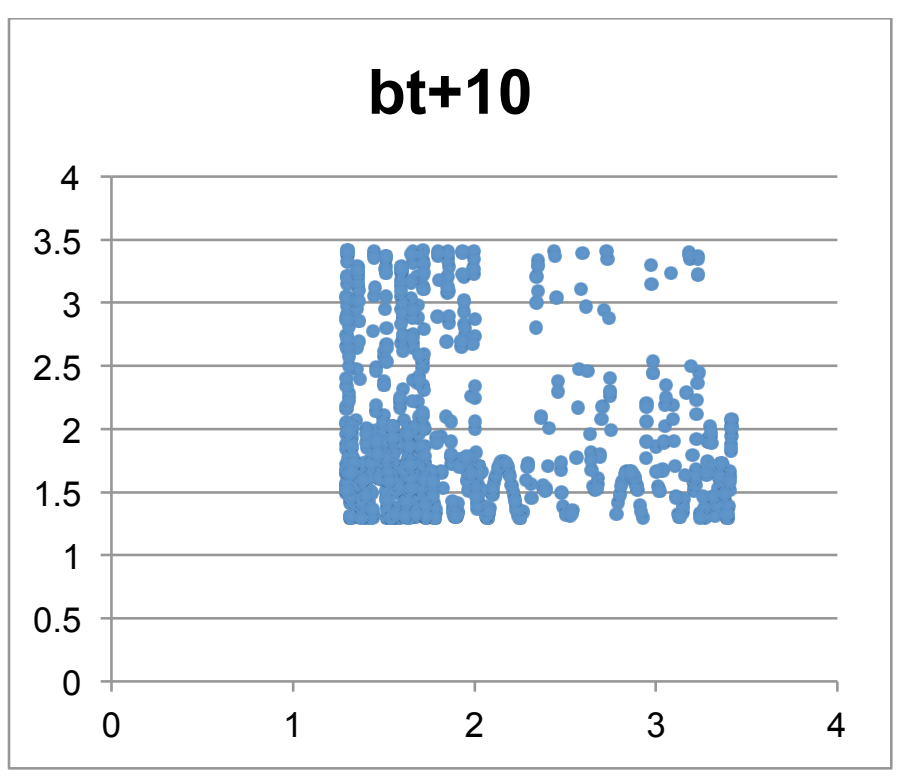

Figure 8 


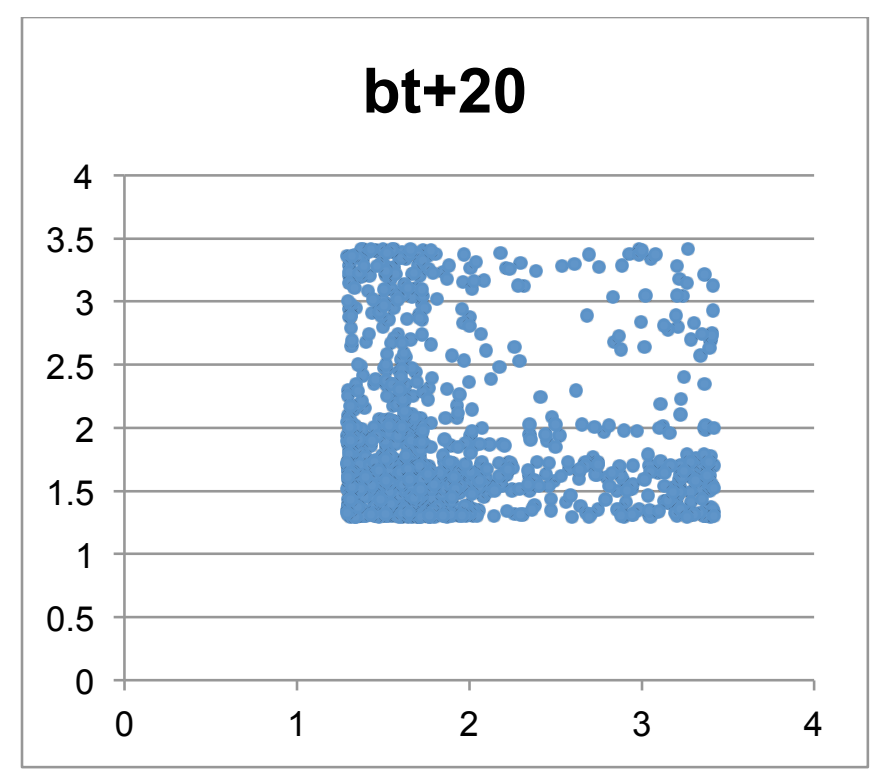

Figure 9

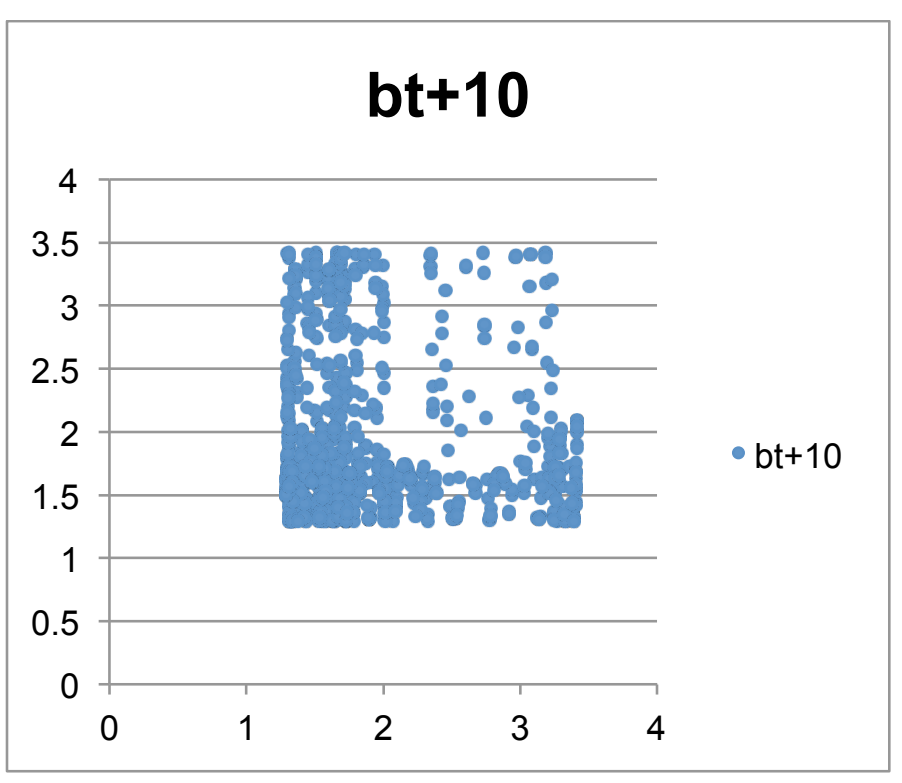

Slight change in initial condition

Figure 10 


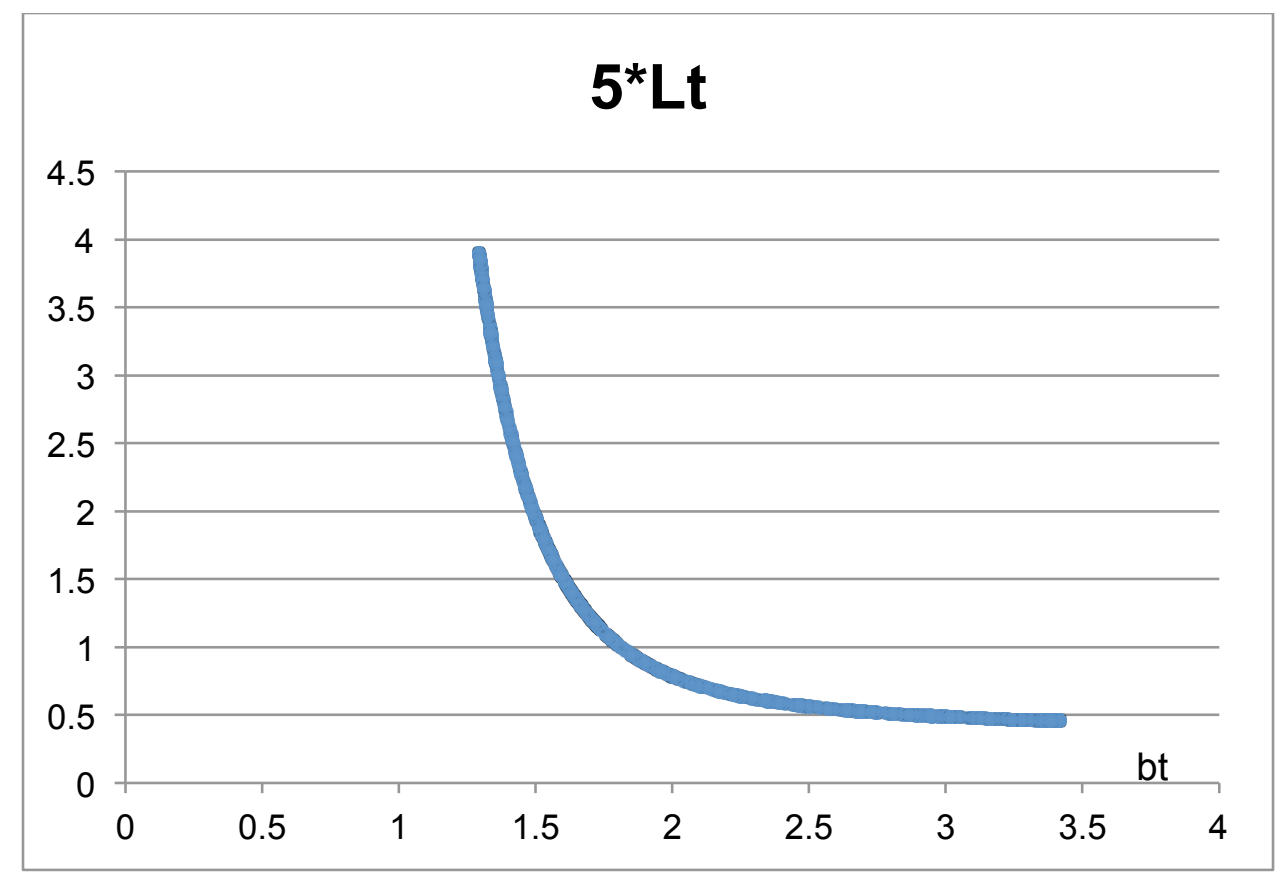

Figure 11

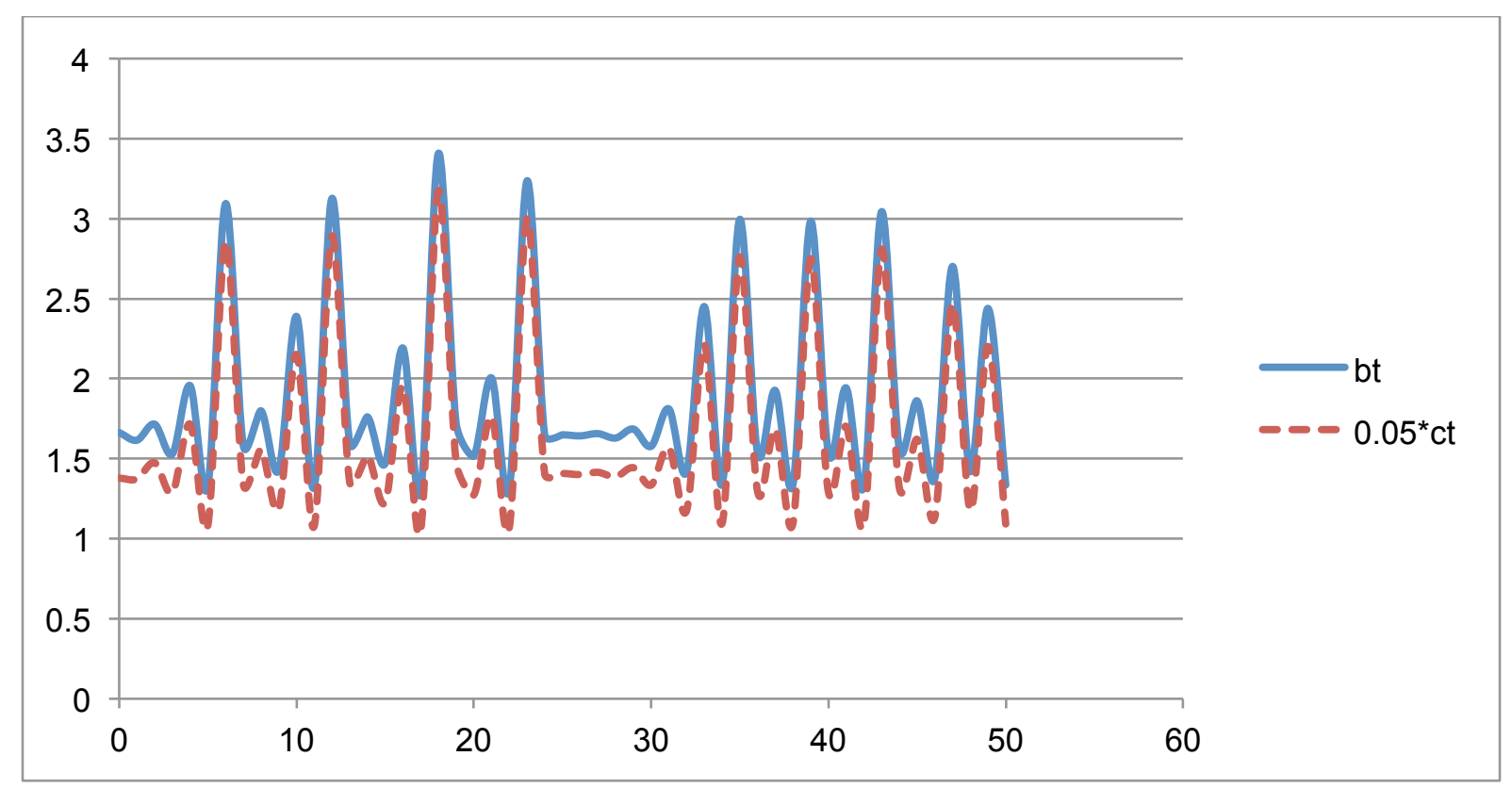

Figure 12 


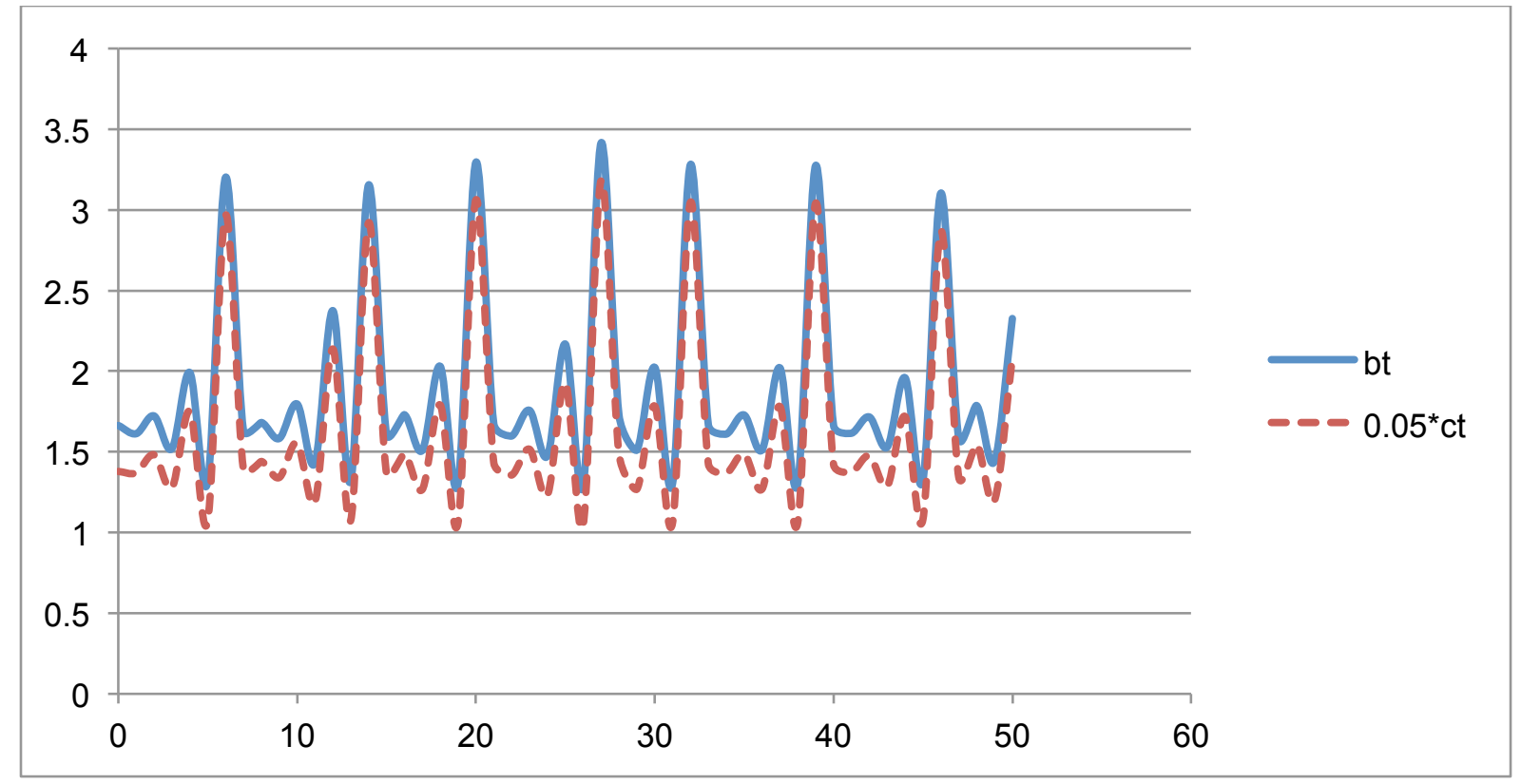

Slight change in initial condition

Figure 13 